\title{
PENINGKATAN PERILAKU ANTI KORUPSI MELALUI METODE STORY \\ TELLING
}

(Penelitian Tindakan TK B Az Zahra, Kebayoran Baru, Jakarta Selatan, Tahun 2016)

\section{DWI PUJI LESTARI}

STAI Al Aqidah Al Hasyimiah Jakarta

J1. Kayu Manis Barat No.99 Jakarta Timur

E-mail: airifaegawa@yahoo.com

\begin{abstract}
Abstrak
Tujuan dari penelitian ini untuk mengambarkan proses penerapan metode story telling untuk meningkatkan perilaku anti korupsi pada TK B A Zahra Kabayoran Baru Jakarta Selatan. Penelitian tindakan kelas mengunakan model Kemmis dan Mc. Taggart. Subjek dari penelitian ini adalah TK B Az Zahra Kebayoran Baru Jakarta Selatan yang berjumlah 16 anak yang terdiri adari 6 perempuan dan 10 laki-laki. Langkah-langkah dalam penelitian ini yaitu: 1) Perencanaan; 2) Pelaksanaan; 3) Pengamatan; 4) Refleksi. Analisa data yang digunakan adalah kualitatif dan kuantitatif. Data kualitatifnya mengunakan model Miles and Hubberman. Penelitian ini dilakukan dalam dua siklus yaitu siklus I dan siklus II. Hasil akhir dari analisa data menunjukan peningkatan sebanyak pada siklus II $88,05 \%$ dari pra siklus sebanyak $41,23 \%$ sampai pada siklus I $72,23 \%$
\end{abstract}

Kata Kunci: Perilaku Anti Korupsi, Metode Story Telling dan Penelitian Tindakan

\begin{abstract}
The purpose of this research was to determinate the proccess of implementation of story telling metode to increase behavior of anti-corruption in Group B Az Zahra Kebayoran Baru South of Jakarta. This research is an action research which refers to the model of a classroom Action Research Kemmis and Mc. Taggart. The subject of this research are children in Group B Az Zahra Kebayoran Baru South of Jakarta there are 16 children, who consist of 6 girls and 10 boys. The steps of this research: 1) Planing (2) Action (3) Observation (4) Reflection. Data analysis used quantitative and qualitative. Data analysis qualitative used Miles and Hubberman model. This research do in two cycles, there are cycle I and II. The end result of the overall analysis of the data is the percentage in 88,05\% cycles II which showed from pre-cycle is $41,23 \%$ up to cycles I $72,32 \%$
\end{abstract}

Keywords: Behavior Of anti-Corruption, Story Telling Metode and Action Research 


\section{Pendahuluan}

Permasalahan bangsa yang mengakar di Indonesia salah satunya adalah korupsi. Berbagai upaya telah dilakukan untuk memberantas korupsi salah satunya adalah penangkapan para koruptor. Dalam sektor pendidikan terdapat pendidikan anti korupsi. Pemberantasan korupsi dalam sektor pendidikan merupakan investasi jangka panjang. Karena pendidikan antikorupsi mempersiapkan generasi penganti untuk melanjutkan kepemimpinan bangsa. Sehingga kedepan negara kita memiliki tingkat korupsi yang sedikit/kecil.

Pendidikan anti korupsi harus dimulai sejak usia dini. Karena pendidikan anak usia dini akan menentukan keberhasilan pendidikan pada jenjang berikutnya. Hal yang dapat dilakukan dalam mencegah korupsi melalui pemberian perilaku anti korupsi pada anak. Para guru mendidik anak melalui perkataan dan sikap anti korupsi baik dalam lingkungan pembelajaran dan luar pembelajaran. Mengugah anak untuk menjadi duta kecil anti korupsi. Sehingga anak akan memiliki semangat anti korupsi yang besar.

Namun pada kenyataannya tidak semua jenjang PAUD yang ada di Indonesia menerapkan pendidikan anti korupsi bagi anak usia dini. Pendidikan di PAUD masih terjebak pada calistung sebagai upaya persiapan menghadapi jenjang pendidikan dasar. Padahal pendidikan anti korupsi ini jauh lebih utama karena akan menjadi modal sosial bagi anak untuk menjalankan kehidupan sehari-hari. Permasalahan-permasalahan sosial anak pun semakin bermunculan diantaranya bullying sesama teman, ketidak jujuran anak dalam belajar misalnya menyontek, berbohong masalah uang saku sekolah, dan anak-anak yang malas untuk belajar padahal belajar merupakan bentuk tanggung jawab anak sebagai pelajar.

Berdasarkan hasil observasi pada 14 Oktober 2014 terdapat delapan belas anak yang terdiri dari tujuh perempuan dan sebelas laki-laki pada TK B Az Zahra, Kebayoran Baru, Jakarta Selatan peneliti menemukan ada sepuluh anak atau 55, $55 \%$ yang berkata tidak jujur karena takut dihukum guru, anak-anak yang tidak bertanggung jawab setelah mengunakan tempat pensil tidak menaruh pada tempatnya, melihat anak yang senantiasa berperilaku tidak mau antri. Ketika diobservasi hanya ada anak Ketika anak disuruh berbagi dengan temannya mereka tidak melakukannya. Sedangkan hasil wawancara awal pada 14 Oktober 2014 terkait dengan perilaku anti korupsi dengan anak-anak TK B Az Zahra dari delapan belas sepuluh atau 55, 55\% anak yang 
tidak mampu menjawab mereka bersikap pasif karena tidak tahu

Sesuai dengan perkembangan sosial emosionalnya anak usia 5-6 tahun merupakan anak yang telah mampu mengendalikan diri/mampu mengontrol dirinya sehingga mampu membedakan perbuatan baik dan buruk maka untuk menyelesaikan berbagai permasalahan tersebut perlu diberikan peningkatan perilaku anti korupsi karena dalam perilaku anti korupsi terdapat nilai-nilai yang didalamnya memuat berbagai nilai-nilai untuk membentuk kepribadian anak. Salah satu hal penting bagi dunia bermain adalah menyenangkan bagi anak. Mendidik perilaku anti korupsi pada anak akan membosankan jika hanya melalui nasihat karena mereka akan mudah lupa terhadap apa yang mereka dengar. Melalui metode story telling anak akan mudah mengingat nilai-nilai anti korupsi karena dalam metode ini begitu menyenangkan sehingga mampu menimbukan kesan pada anak. Maka dengan demikian metode ini akan efektif apabila digunakan untuk mengajarkan perilaku anti korupsi pada anak usia dini.

\section{Perilaku Anti Korupsi}

Notoatmodjo dalam Jamaris (2013:118) perilaku adalah tindakan atau aktivitas dari manusia itu sendiri yang mempunyai bentangan yang sangat luas antara lain: berjalan, berbicara, menangis, tertawa, bekerja, kuliah, menulis, membaca, dan sebagainya. Dari uraian ini dapat disimpulkan bahwa yang dimaksud perilaku manusia adalah semua kegiatan atau aktivitas manusia, baik yang diamati langsung, maupun yang tidak dapat diamati oleh pihak luar. Soekidjo (2003: 87) perilaku dapat diartikan sebagai suatu respons organisme atau seseorang terhadap rangsangan dari luar subjek tersebut. Sedangkan Santrock (2007: 128) perilaku atau tindakan moral merupakan ketrampilan kompetensi atau kemampuan untuk mengaplikasikan keputusan dan perasaan moral kedalam tindakan konkret. Kemampuan untuk mewujudkan nilai dalam hal kecil agar lebih mudah melakukan tindakan baik dalam hal besar.

Syarbini dan Arbain (2014: 6) mengatakan sikap anti korupsi merupakan sikap tidak setuju, tidak suka dan tidak senang terhadap tindakan korupsi. Anti korupsi merupakan sikap mencegah dan menghilangkan bagi berkembangnya korupsi. Mencegah adalah meningkatkan kesadaran individu untuk tidak melakukan tindak korupsi. Senada dengan Nurdin (2014: 174) anti korupsi merupakan sikap tidak setuju, tidak suka dan tidak senang terhadap tindakan korupsi. Anti korupsi merupakan sikap mencegah dan menghilangkan peluang untuk korupsi. Hal tersebut ditegaskan oleh Tamogola dalam Kamil (2013: 28) mengatakan bahwa 
menurut sebagian ahli kata anti korupsi sudah termasuk dalam Integritas. Artinya sikap anti korupsi adalah salah satu bagian
Menurut Wijaya (2014: 229) adapun Indikator pendidikan anti korupsi untuk pendidikan anak usia dini:

Tabel Indikator Pendidikan Anti korupsi untuk PAUD

\begin{tabular}{|c|c|c|}
\hline No & Nilai & Indikator \\
\hline 1 & Kejujuran & $\begin{array}{l}\text { Tidak mengambil mainan atau barang milik teman, Melapor apa bila } \\
\text { menemukan barang hilang, Memberitahu guru apabila melihat barang } \\
\text { teman yang tertinggal, Melaporkan dengan jujur apabila kehilangan } \\
\text { atau ketinggalan barang milik sendiri, selalu menceritakan terus } \\
\text { terang apabila ada masalah, mengembalikan barang yang dipinjam, } \\
\text { mengakui kesalahan. }\end{array}$ \\
\hline 2 & Kepedulian & $\begin{array}{l}\text { Mengingatkan teman jika barangnya tertinggal dikelas, ikut } \\
\text { membantu barang teman yang hilang, menjaga dengan baik barang } \\
\text { yang dipinjam dari teman }\end{array}$ \\
\hline 3 & Kemandirian & Tidak selalu bergantung pada bantuan orang lain, tidak minta dilayani \\
\hline 4 & Kedisiplinan & $\begin{array}{l}\text { Terbiasa mengerjakan pekerjaan sesuai dengan aturannya (bangun, } \\
\text { tidur, istirahat, belajar dan bermain tepat waktu), terbiasa datang ke } \\
\text { sekolah lebih awal, masuk kelas tepat waktu, menyelesaikan } \\
\text { pekerjaan hingga tuntas dan tepat waktu dan terbiasa antri dalam } \\
\text { berbagai hal) }\end{array}$ \\
\hline 5 & Tanggung Jawab & $\begin{array}{l}\text { Membereskan peralatan setalah digunakan dan tidak mengunakan } \\
\text { pekerjaan yang bukan menjadi tugasnya. }\end{array}$ \\
\hline 6 & Kerja Keras & $\begin{array}{l}\text { Selalu bersemangat mengerjakan tugas(membersihkan diri, } \\
\text { mengambar dan menyanyi), berusaha menyelesaikan pekerjaan yang } \\
\text { diberikan guru dengan baik, memiliki keinginan dan cita-cita menjadi } \\
\text { orang baik dan tidak mudah menyerah. }\end{array}$ \\
\hline 7 & Kesederhanaan & $\begin{array}{l}\text { Membawa makanan tidak berlebihan, membawa makanan dari } \\
\text { rumah, mengunakan pakaian bersih, rapi dan tidak berlebihan. }\end{array}$ \\
\hline 8 & Keberanian & $\begin{array}{l}\text { Berani melapor ketika salah, misal merusak mainan teman, berani } \\
\text { bertanya sebelum melakukan tugas yang diberikan guru }\end{array}$ \\
\hline 9 & Keadilan & $\begin{array}{l}\text { Tidak memilih-milih teman, tidak minta untuk diistimewakan, rela } \\
\text { berbagi dengan teman dan tidak menang sendiri }\end{array}$ \\
\hline
\end{tabular}

dari integritas. Orang yang tidak korup

artinya berintegritas. 
Sehingga dapat kita ambil kesimpulan bahwa perilaku anti korupsi adalah tindakan yang mengambarkan sikap tidak setuju, tidak suka dan tidak senang terhadap tindakan korupsi sehingga akan melakukan tindakan pencegahan terhadap korupsi terhadap diri sendiri dan orang lain. Orang yang berperilaku anti korupsi akan memiliki sembilan kriteria yaitu jujur, berani, bertanggung jawab, mandiri, disiplin, adil, sederhana, peduli, dan kerja keras.

\section{Metode Story Telling}

Semiawan (2007:34) mengemukakan bahwa cerita merupakan wahana yang ampuh untuk mewujudkan pertemuan (ecounters) seperti itu. Keasyikan dalam menyelami substansi cerita. Apalagi si pencerita dapat demikian dalam menyelami materinya sehingga memasuki dunia minat (center of interest) anak tersebut dan menghasilkan apa yang oleh moslow (1968) disebut penghayatan pengalaman yang paling mendalam (peakexperience). Terjadinya pertemuan tersebut merupakan peluang untuk mengkoorporasikan segi-segi pedagogis dalam cerita tersebut mempengaruhi perkembangan pribadinya membentuk sikap-sikap moral dan keteladanan.

Mal (2008: 3) bahwa bercerita merupakan suatu seni dalam menyampaikan ilmu, pesan, nasehat kepada orang lain baik bagi anak-anak, remaja maupun orang tua. Claire (2005: 12) juga menyatakan bahwa bercerita adalah sebuah bentuk seni yang tidak hanya menyeberangi batas waktu dan budaya, tetapi merupakan wahana untuk menyampaikan pengetahuan, perasaan, pikiran, dan gagasan. Heroman dan Jones dalam Rahayu (2013: 80) mengemukakan bercerita merupakan salah satu seni, bentuk hiburan, dan pandangan tertua yang telah di percayai nilainya dari generasi ke generasi berikutnya. Moeslichatoen (2004: 157) bercerita atau story telling merupakan metode pemberian pengalaman belajar bagi anak dengan membawa cerita kepada anak secara lisan.

Dari berbagai pendapat para ahli diatas dapat disimpulkan bahwa metode story telling merupakan seni yang disampaikan secara lisan yang tidak hanya menyeberangi batas waktu dan budaya akan tetapi juga menyampaikan ilmu pengetahuan, pesan, nasehat, gagasan, pikiran, perasaan dan pengalaman kepada orang lain yang meliputi anak-anak, remaja maupun orang tua sehingga penerima cerita akan menghayati cerita dan dapat memperngaruhi pribadinya membentuk moral dan keteladanan.

\section{Metode Penelitian}

Metode dalam penelitian ini adalah penelitian tindakan dengan menggunakan model Kemmis dan Taggart. Yang terdiri dari empat komponen, yaitu: perencanaan 
(planning), tindakan (acting), pengamatan (observing), dan refleksi (reflecting).

Tekhnik pengumpulan data dalam penelitian ini adalah menggunakan (a) observasi pemantau tindakan pada anak dan guru (b) wawancara dan (c) dokumentasi.

Jenis instrumen yang digunakan adalah menggunakan non tes berupa berbentuk lembar observasi pemantauan tindakan.

Teknik analisis data yang dilakukan dalam penelitian ini adalah melalui dua cara yaitu teknik analisis kuantitatif deskriptif dan data kualitatif. Statistika deskriptif untuk membandingkan hasil yang diperoleh dari siklus pertama dan siklus kedua berupa rata-rata angka hitung (mean) dan perhitungan/pengukuran berbentuk prosentase. Analisis data kualitatif dilakukan terhadap data yang dikumpulkan melalui wawancara, catatan lapangan peneliti, dan refleksi.

\section{Hasil dan Pembahasan}

Berikut adalah hasil penelitian peningkatan perilaku anti korupsi melalui story telling

\section{Pra-Siklus}

Dari data prilaku anti korupsi pada anak pra-penelitian dapat disajikan dalam bentuk grafik maka hasilnya sebagai berikut:

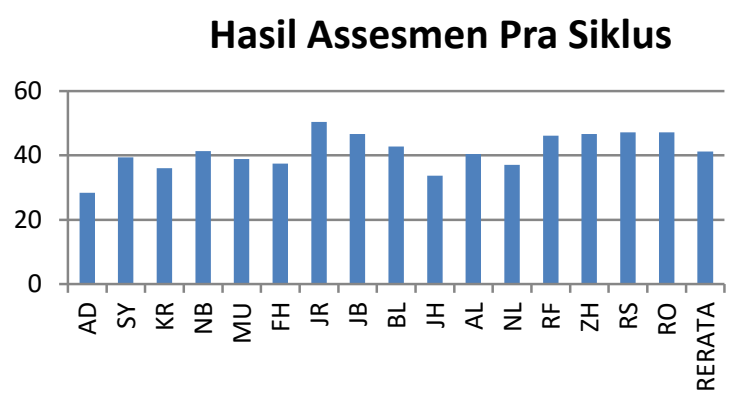

Gambar 4.1 Grafik Perilaku Anti Korupsi

Pra siklus

Grafik tersebut mengambarkan bahwa perilaku anti korupsi pada TK B Az Zahra Kebayoran Baru Jakarta Selatan yaitu persentase $41,23 \%$.

Setelah mengetahui hasil peneliti bersama kolaborator melakukan analisis dan berdiskusi tentang hasil dari assesmen pra siklus. Setelah dianalisa secara mendalam. Maka peneliti dan kolaborator memutuskan untuk melaksanakan tindakan intervensi yaitu pelaksanaan siklus I karena nilai hasil assesmen pra siklus berada dibawah das sein dan masih jauh dari standar keberhasilan yang telah disepakati antara kolaborator dan peneliti yakni $71 \%$.

\section{Siklus I}

Hasil Assesmen Siklus 1

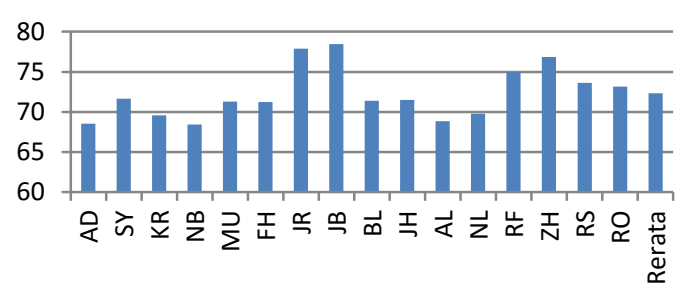

Gambar 4.2 Grafik Hasil Asesmen

Perilaku Anti Korupsi Anak Siklus I

Berdasarkan grafik diatas, diperoleh data tentang perilaku anti korupsi anak pada siklus I, yaitu rata-rata 16 anak dengan persentase sebesar $78,85 \%$ diperoleh oleh JB dan persentase terendah dengan $68,43 \%$ diperoleh oleh NB. Secara 
klasikal diperoleh persentase 72,32 artinya pelaksanaan pada siklus I telah mencapai kriteria keberhasilan yang telah disepakati diawal bersama kolaborator dan mastery learning yang ada di sekolah yakni sebesar $71 \%$.

Untuk mengetahui konsistensi hasil pelaksanaan penelitian siklus I maka peneliti dan kolaborator menyepakati untuk melanjutkan ke siklus II. Berikut hasil perkembangan perilaku anti korupsi dari pra siklus hingga siklus I.

Berikut adalah hasil asesmen dari pra siklus hingga siklus I:

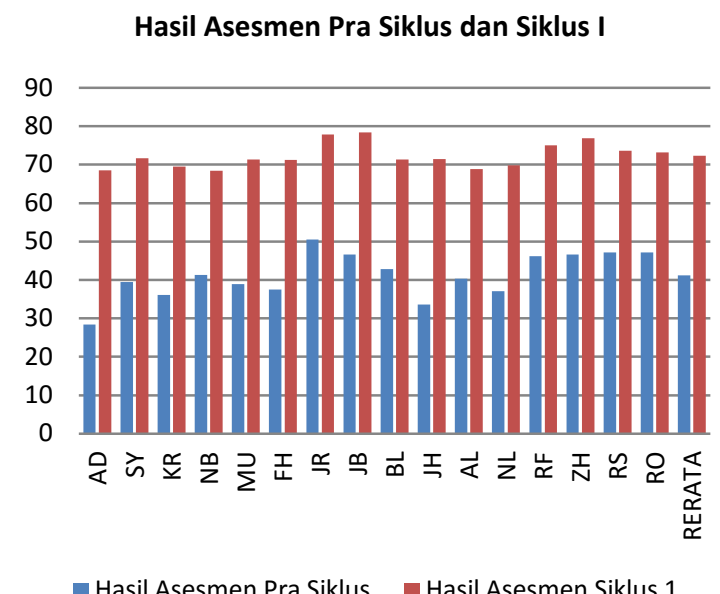

Gambar 4.3 Grafik Perilaku Anti Korupsi dari Pra siklus hingga Siklus I Berdasarkan data hasil perkembangan perilaku anti korupsi pada anak yang berjumlah 16 orang dapat dilihat saat pra-siklus mencapai persentase sebesar $41,23 \%$ dan pada siklus I persentase sebesar 72,32\%. Hal ini menunjukkan rata-rata kenaikan perilaku anti korupsi anak dengan persentase sebesar 31,09\%.
Peneliti dan kolaborator melakukan refleksi setelah pelaksanaan siklus I telah selesai dilaksanakan. Ada beberapa hal yang menjadi bahan refleksi peneliti dan kolaborator pada siklus I baik itu berupa kelemahan maupun kelebihan. Adapun hasil refleksi tersebut, yaitu:

a) Anak duduk belum membentuk circle karena mereka penasaran dengan gambar yang ada dalam buku yang digunakan untuk bercerita

b) Ketika guru bercerita ada beberapa anak yang menceritakan pengalamannya sehingga anak yang lain mengikuti ingin bercerita juga.

c) Guru terlihat kesulitan ketika beberapa anak sudah mulai tidak mau mendengarkan

d) Beberapa anak merespon dengan cepat pertanyaan dari guru.

e) Beberapa anak mau bertanya kepada guru ketika mengalami kesulitan

f) Terlihat beberapa anak yang mulai menunjukan Perilaku anti korupsi

g) Setiap pertemuan ada beberapa anak selalu menceritakan pengalaman yang dilakukan dirumah sesuai dengan cerita.

h) Perubahan suara dan gerak gerik dalam bercerita membuat anak antusias mendengarkan cerita kemampuan guru dalam story telling sudah baik

i) Anak-anak sangat tertarik ketika guru memberikan reward kepada anak ketika anak mampu menjawab pertanyaan guru 
j) Anak selalu bercerita kepada guru tentang sikap mereka berbagi kepada teman, menaruh tas pada tempatnya, menabung, menjadi nomor satu ketika mengerjakan tugas, dan tidak menyontek selama belajar.

Karena masih ada kekurangan dalam siklus I maka diputuskan untuk melanjutkan ke siklus II.

\section{Siklus II}

Adapun hasil dari siklus II adalah sebagai berikut:

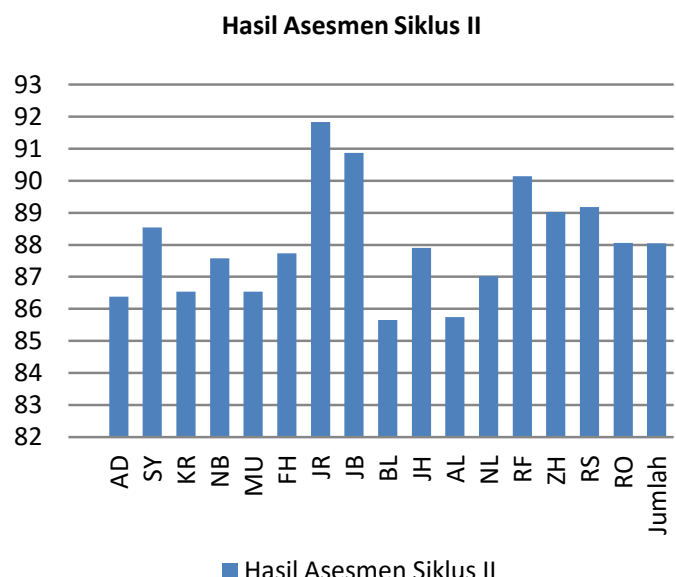

Gambat 4. 4 Grafik Hasil Asesmen

Pelaksanaan Siklus II

Berdasarkan hasil tabel dan grafik diatas, diperoleh data tentang perilaku anti korupsi anak pada siklus II dari 16 anak secara klasikal memiliki persentase sebesar $88,05 \%$ artinya pelaksanaan pada siklus II terjadi peningkatan dari pelaksanaan siklus I sebesar persentase $72,32 \%$ maka dari dapat diambil kesimpulan bahwa pelaksanaan siklus II telah mencapai nilai yang telah disepakati diawal bersama kolaborator dan mastery learning yang ada di sekolah yakni sebesar $71 \%$.

Berikut hasil asesmen perilaku anti korupsi dari pra siklus, siklus I hingga siklus II

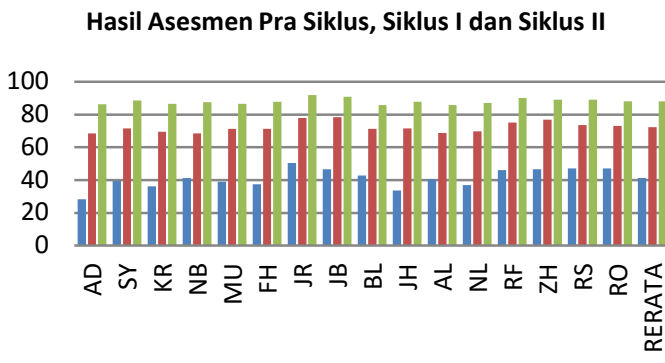

- Hasil Asesmen Pra Siklus Hasil Asesmen Siklus 1 - Hasil Asesmen Siklus II

Gambar 4.5 Grafik Perbandingan Pra siklus, Siklus I dan Siklus II

Berdasarkan data peningkatan perilaku anti korupsi terlihat bahwa ratarata persentase skor pra siklus anak sebesar $41,23 \%$ meningkat pada siklus I sebesar 31,09\% sehingga menjadi $72,32 \%$, selanjutnya dari siklus I ke Siklus I Perilaku anti korupsi pada anak juga mengalami peningkatan sebesar $15,73 \%$ dari $72,32 \%$ menjadi $88,05 \%$. Sehingga total peningkatan perilaku anti korupsi siswa mulai dari pra siklus, siklus I sampai siklus II $46,82 \%$ yaitu dari $41,23 \%$ menjadi $88,05 \%$.

Maka dapat kita lihat bahwa dalam penelitian ini terjadi peningkatan perilaku anti korupsi melalui metode story telling dari pra siklus ke siklus I dan siklus II secara kuantitatif yaitu dari pra siklus sebesar $41,23 \%$ meningkat pada siklus I sebesar 31,09\% sehingga menjadi 72,32\%, 
selanjutnya dari siklus I ke Siklus II Perilaku anti korupsi pada anak mengalami peningkatan sebesar $15,73 \%$ dari $72,32 \%$ menjadi $88,05 \%$. Sehingga total peningkatan perilaku anti korupsi anak mulai dari pra siklus, siklus I sampai siklus II sebesar $46,82 \%$.

Apa bila penelitian ini dilihat dari berbagai multidisiplin ilmu maka dapat diuraikan sebagai berikut:

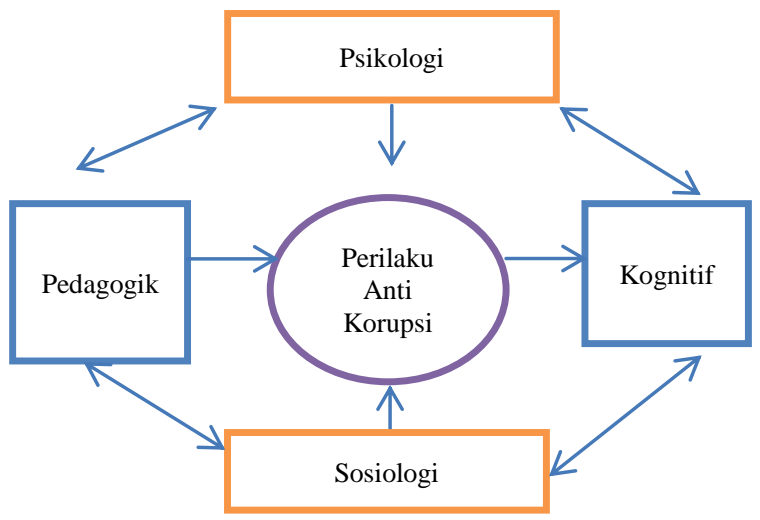

Gambar 4.1 Bagan Multidipliner Perilaku

Anti Korupsi Dengan Penerapan Metode Story Telling

Santrock (2009: 3) dalam kajian ilmu psikologi, mengemukakan bahwa psikologi merupakan studi ilmiah mengenai perilaku dan proses mental. Psikologi dalam temuan peneliti diperoleh tentang pengaruh lingkungan belajar terhadap perilaku anak yang merupakan perwujudan dari hasil peningkatan prilaku anti korupsi melalui metode story telling. Selanjutnya dalam kajian pedagogik, menurut Hoogveld dalam Sadulloh (2012: 2) pedagogik merupakan ilmu yang mempelajari masalah membimbing anak ke arah tujuan tertentu yaitu supaya anak mampu untuk menyelesaikan tugas hidupnya. Berdasarkan hasil penelitian bahwa melalui metode story telling berhasil meningkatkan perilaku anti korupsi kepada anak sehingga dapat dijadikan dasar dalam berperilaku. Apa bila dilihat dari sudut pandang kognitif, Nurani (2004: 311) menjelaskan menurut pieget anak usia dini berada dalam Tahap pra-operasional, yang berkisar pada usia 2-7 tahun, pada tahap ini anak mempunyai gambaran mental dan mampu untuk berpura-pura, langkah pendek untuk menggunakan symbol. Diperjelas oleh Desmita (2009: 34) perkembangan kognitif meliputi perubahan pada aktivitas mental yang berhubungan dengan persepsi, pemikiran, ingatan, keterampilan berbahasa dan pengolahan informasi yang memungkinkan seseorang memperoleh perilaku, memecahkan masalah, dan merencanakan masa depan, atau semua proses psikologis yang berkaitan dengan bagaimana individu mempelajari, memperhatikan, mengamati, membayangkan, memperkirakan, menilai dan memikirkan lingkungannya. Dari aktivitas pembelajaran story telling maka telah menginternalisasi nilai anti korupsi pada anak sehingga dapat dijadikan sebagai dasar pengetahuan untuk mengambil keputusan berperilaku. 
Disiplin ilmu sosiologi menurut Edwi (2011: 83) adalah ilmu yang mempelajari hubungan sosial antara sesama manusia (individu dan individu), antara individu dan ide-ide social. Penelitian ini akan bermanfaat untuk kesuksesan anak dalam bersosialisasi dengan lingkungan karena dengan anak memiliki nilai-nilai anti korupsi maka anak akan dapat berperilaku dengan baik kepada lingkungan sosialnya sehingga anak akan diterima oleh lingkungan. Sehingga masing-masing disiplin ilmu memiliki hubungan yang saling mendukung.

\section{Simpulan}

Berdasarkan hasil analisis data dalam pembahasan, maka dapat disimpulkan sebagai berikut:

Dengan metode story telling dapat meningkatkan perilaku anti korupsi di TK B Az Zahra Kebayoran Baru Jakarta Selatan. Hal ini dibuktikan dengan data hasil pra siklus I, pelaksaan siklus I dan siklus III Dan data hasil pelaksanaan kegiatan menunjukan bahwa terjadi peningkatan Perilaku anti korupsi pada anak. Dari sembilan aspek yaitu kejujuran, kepedulian, kedisiplinan, tanggung jawab, kesederhanaan, kemandirian, keadilan, kerja keras dan keberanian. Setiap anak mengalami peningkatan kemampuan sesuai dengan kriteria keberhasilan yang telah disepakati antara peneliti dan kolaborator. Selain itu beberapa temuan yang didapatkan dalam penelitian ini yaitu: keberhasilan siklus II sangat dipengaruhi oleh beberapa hal antara lain 1) Keberhasilan guru dalam melaksanakan metode Story Telling. 2) Kegiatan yang dilakukan dari siklus I dan II semakin baik sehingg terjadi adanya peningkatan secara kuantatif yaitu siklus I diperoleh hasil sebesar 72,32\%. Pada siklus II Perilaku anti korupsi anak juga mengalami peningkatan sebesar $15,73 \%$, dimana pada siklus II anak Memperoleh hasil sebesar $88,05 \%$. hal ini terbukti bahwa penerapan metode story telling dapat meningkatkan Perilaku anti korupsi pada anak.

\section{Rekomendasi}

Bagi guru diharapkan dapat membudayakan metode story telling kepada anak-anak untuk menanamkan perilaku anti korupsi pada anak di sekolah. Kemudian bagi orang tua, diharapkan orang tua anak dapat mendukung perkembangan perilaku anti korupsi yang telah diajarkan di sekolah. Dengan adanya kerjasama antara guru dan orang tua, maka perilaku anti korupsi yang didapatkan akan membudaya dalam diri anak. Terakhir bagi peneliti lain diharapkan mau mengembangkan penelitian ini dan lebih banyak memperkaya sumber-sumber yang mendukung baik itu secara nasional atau internasional.

\section{Daftar Pustaka}


Arbain, Muhammad dan Amirullah Syarbini, Pendidikan Anti Korupsi: konsep, strategi dan implementasi pendidikan anti korupsi di sekolah/madrasah, Bandung: Alfabeta, 2014

Claire, Jeninng Children as Story-Tellers. Developing Language Skills in the Classroom, alih bahasa oleh Haniah, Melbourne, Oxford University Press, 2005

Desmita, Psikologi Perkembangan Peserta Didik, Bandung: Remaja Rosdakarya, 2009

Jamaris, Martini, Orientasi Baru dalam Psikologi Pendidikan, Bogor: Ghalia Indonesia, 2013

Edwi, Nugrohadi G, Haryanto Dany, Pengantar Sosiologi Dasar (Jakarta: PT. Prestasi Pustakaraya, 2011) h. 83.

Kak Mal, The Power Of Story Telling, Depok: Metro Media, 2008

Kamil ,Sukron et al., Korupsi dan Integritas dalam Ragam Perspektif, Jakarta: PSIA, 2013

Moeslichatoen, Metode Pengajaran di Taman Kanak-kanak, Jakarta: Rineka Cipta, 2004

Nurani, Sujiono Yuliani dkk, Metode Pengembangan Kognitif Jakarta: Universitas Terbuka, 2004

Nurdin, Muhammad Pendidikan Anti Korupsi; Strategi Internalisasi nilainilai Islami dalam menumbuhkan kesadaran anti korupsi, Yogyakarta: Ar-ruzz Media, 2014

Sadulloh, U. dkk. Pedagogik (Ilmu Mendidik), Bandung: Alfabeta, 2012
Santrock, John W, Perkembangan Anak, Jakarta: Erlangga, 2007

Santrock, Psikologi Pendidikan, Jakarta: Salemba Humanika, 2009

Semiawan, Cony, Landasan Pembelajaran dalam Perkembangan Manusia Jakarta: Center For Human capacity Development, 2007

Soekidjo, Notoatmodjo, Pendidikan dan Perilaku Kesehatan, Jakarta: Rineka Cipta, 2003

Rahayu, Aprianti Yovita Menumbuhkan Kepercayaan Diri Melalui Bercerita, Jakarta: Indeks, 2013 